

\title{
Contingency Management in Indian Construction Projects
}

\author{
H. Maniar ${ }^{1}$ \\ ${ }^{1}$ Professor in Finance \& Cost Management, L\&T Institute of Project Management, Vadodara, India
}

Received 6 June 2019; received in revised form 3 October 2019 and 29 May 2020; accepted 14 November 2020 https://doi.org/10.15641/jcbm.4.2.788

\begin{abstract}
The successful completion of Indian construction projects possesses an inherent uncertainty due to the nature of the construction industry along with prevailing tepid recovery of the Indian economy, which has made it difficult for construction companies to achieve required operational and financial performance. This necessitates having accurate project cost estimation and efficient contingency management to shield unknown project risk and address cost overrun problems. Therefore, this study aims to assess the current state, the issues faced in contingency management and evaluating the effectiveness of contingency in overcoming cost overrun problems in Indian construction companies. The study preferred a quantitative approach in capturing the required data by using structured questionnaires collected from 100 Indian construction companies (of contractors, vendors/suppliers, customers, and consultants) out of 335 companies with a response rate of $29.85 \%$. This, along with archival data analysis of 50 Indian construction projects completed between Calendar Year (CY) 2014 to 2019. The captured data were analysed using simple statistical tools like Relative Importance Index (RII), mean score, standard deviation and ranking methods to ensure relevant results aligned with research objectives. The result findings of the study revealed that $60 \%$ of Indian construction companies preferred the traditional percentage method for contingency sum percentage addition to estimated project cost (a subjective approach based on the historical project performance) which may not be adequate in overcoming cost overrun problems. Archival data analysis found that contingency consideration was effective in accommodating cost overrun problems in 9 (18\%) projects out of 50 projects. The study further found that contingency was utilised in an unplanned mode and having unclear contingency forecasting strategies. Based on result findings and observations, this study concludes that contingency should be estimated based on the scientific approach in place of a subjective approach to address project risks adequately, this along contingency consideration should be an integral part of the project risk assessment and should be effectively utilised during the execution stage.
\end{abstract}

Keywords: Contingency, Cost Overruns, Indian Construction Projects, Operational and Financial Performance, Project Risk.

\section{Introduction}

Indian construction companies have been subject to severe financial stress due to factors including the slow rate of macro-economic recovery, implementation of farreaching policies such as Goods and Services Tax (GST) and Demonetisation by the Government of India within a short period (CMIE (Centre for Monitoring Indian Economy) Report, 2019). This, along with projectspecific factors such as competitive bidding prices, unwarranted delays, unpredictable revenue and margins, variable resource rates, and uncertain site conditions create both opportunities and challenges for construction companies (Jimoh et al., 2014). As per the study conducted by the Construction Industry Development Council (CIDC) of India ; the cost structure of Indian construction projects is significantly dominated by material cost $(40 \%-45 \%)$ and sub-contracting charges $(20 \%-25 \%)$. Therefore, it is imperative for Indian construction companies to optimally estimate project cost and effective utilised project resources. This, along with suitable provisions of contingency to safeguard project budget against any adverse upswing or overspend which

\footnotetext{
${ }^{1}$ Corresponding Author.

Email address: hmaniar@Lntipm.org
} 
can affect the operational and financial performance of the construction projects.

Considering these impending factors, increasing project bid price is not an effective choice because of unpredictable market conditions, project time and scope commitments to the customers apart from a fear of losing the competitive edge in the market (Kim et al., 2008). Therefore, to defend project cost and margins, adequate contingencies should be considered in project cost baseline (CBL) to empower project managers with required flexibility in overcoming cost overruns and accommodating unknown project risks (Touran, 2003). Hence, construction companies should make suitable provision of a contingency to accommodate slippage due to price escalations of resources; scope/design changes; possible underestimation during the proposal stage or cost overruns in the execution stage (Hart, 2007). In prevailing situations, managing construction project cost is a significant and challenging task for Indian construction companies, unlike their global counterparts.

The study had preferred a questionnaire survey and archival data of previously completed projects for data collection and analysis. The questionnaire survey method was mainly used for gathering required project data to understand key aspects and features of contingency management in Indian construction companies. The study also used archival data of 50 Indian construction projects completed between CY (calendar year) 2014 to 2019 . The primary intent of using archival data analysis was to assess the impact of contingency in understanding the relationship between the estimated cost and actual cost for completed projects for measuring utilisation of contingency in studied projects.

In the present state of executing price-sensitive construction projects, this study aimed in assessing the current state, the issues faced in contingency management and evaluating the effectiveness of contingency in overcoming cost overrun problems in Indian construction companies. Therefore, for the attainment of study aim; required objectives firmed-up and targeted through the study, the objectives are as follows:

- To study Indian construction companies' awareness and approach towards contingency management along with various factors affecting contingency in the overall project performance.

- To elicit the opinions of surveyed project companies regarding the impact of the factors affecting contingency estimation and the degree of consideration of these factors in the project estimated cost.

- To identify and assess contingency provision in project estimated cost along with its effectiveness in overcoming cost overrun problems.

- To evaluate the adequacy of contingency reserve to improve project performance along with contingency management practices adopted in Indian construction projects.

The rest of the research paper is structured in multiple sections where section-2 represents literature review, section-3 research methodology, section-4 results and discussion of findings and section-5 represents conclusions and recommendations.

\section{Literature Review}

Contingency management in construction projects has been a research topic in focus since long, and many researchers have worked in a wide-ranging manner. Various past studies and their recommendations have been referred for this study and are briefly summarised below;

Contingency can be defined as a project reserve or buffer, according to Baccarini (2004). Based on study observations, contingency is a buffer or provision added to estimated project cost baseline to accomplish project commitments in terms of time, scope, quality and cost to accommodate likely changes as per contract specifications. A study undertaken by AACE (2008) indicates that contingency is buffer or provision considered to cost baseline (CBL) estimate to accommodate unknown risk due to project conditions, unforeseen situations which may increase project cost in addition to the estimated cost. AACE (2008) study also recommended inclusions and exclusions of contingency in the construction projects.

Similarly, according to Akinsola (1996), contingency is essential for achieving the required operational and financial performance for construction projects. According to the study, contingency is integral to project baseline cost, which empowers project managers to mitigate project uncertainties and deviations that imperil project performance. Paper has utilised neural network for cost contingency estimation contrasted with traditional judgemental methods. Research additionally mentioned that considering the nature of construction projects and different objectives which requires the innovation or logical techniques to understanding the required outcome. Subsequently, because of this uniqueness, the estimated project contingency allowance because presumption and observation are lacking and unfeasible.

In construction projects, contingencies are usually calculated as a percentage to estimate cost which depends on the type of contract, scope, quality and commitment of various project stakeholders like contractors, vendors, and suppliers (Lorance et al., 2001). Amade et al., (2014) had investigated scenario of contingency in Nigerian projects which revealed that contingency is estimated using the traditional percentage and arbitrary conventional methods. It further highlights that most construction projects prefer traditional percentage method to estimate contingency which is usually up to $10 \%$ of the estimated cost to accommodate unknown risk.

Apart from this, contingency percentage addition to estimated cost depends on the various projects related factors like location, site challenges, nature and complexity of work, the quantum of work and timeframe of the project (Jimoh et al., 2014). The study has assessed the relationship between contingency sum and client objectives related to budget, schedule, scope, and quality for delivering committed project performance in the study undertaken for the renovation of public school facilities in Abuja. Akinradewo et al., (2016) have studied 53 projects completed in Ondo State, Nigeria, reveals that average contingency was about $5 \%$ while average spending was $18 \%$ higher than estimated cost which shows that contingency was insufficient by $13 \%$. The study further observed that contingency estimated using the traditional 
percentage method was insufficient, and it further proposed that the distribution of contingency provision should be based on cost examination of related finished projects.

Adoption of contingency estimation technique depends on many factors; according to the study conducted by Khalafallah et al., (2005) on estimating residential project contingencies by using belief network framework. It recommended a system for estimating cost contingencies during the project proposal stage based on causal belief network and risk contingency model considering various factors that cause project time and cost overrun using belief network on lump sum residential building projects. El-Kholy (2015) through his study on construction contractors in Egypt, had suggested two models called regression analysis and case-based reasoning (CBR) model for estimating contingency which largely depends on cost escalation in construction projects. According to the study, 11 significant causes were identified, and the dependent variable was the cost overrun percentage. Research further highlighted that the regression model has prediction capabilities higher than that of the CBR model, and the same has been considered as vital information/input for contingency consideration in construction projects.

According to Hart (2007), contingency is a fixed sum or percentage of a baseline estimate considered with the precondition for utilisation of contingency for unknown scenarios. Defined scenarios like price escalations due to unexpected cost increment in project resources; changes in degree or defects/errors that are acknowledged during project execution; possible underestimation during proposal stage or cost overspending during the execution stage. The selection of the right contingency estimation technique is vital as it decides its effective utilisation during the execution stage. Razali Hamid et al. (2017) have studied highway construction projects in Nigeria, which revealed that there was no definite method for estimating contingency in studied projects. The study had further recommended that selection of contingency estimating method depends on the uniqueness of projects, simplicity in utilising selected methods along with the precision of the estimates.

Construction projects due to its inherent characteristics are full of uncertainties and unknown risk, which has compelled the consideration of contingency as an addition to estimated construction cost. Baccarini (2003) on the study undertaken for two diverse construction/engineering and information technology companies, concluded that there is no connection between project-specific variables and estimated project cost baseline (CBL). Furthermore, in studied projects, the contingency was computed subjectively, which limits its effectiveness as it was based on perception, previous project information and expert advice. The study further recommends that critical success factors for contingency estimation depend on cost, time, quality and scope along with associated risks.

According to Buertey et al., (2012), contingency estimation is usually based on accessible historical data, judgemental and prevailing organisational culture, which is by all accounts unempirical and lacking. The study recommends contingency estimating process and proposes a framework and the same was tested in the form of questionnaires among targeted project customers, contractors, vendors, suppliers, and connected project professionals to check the viability of the suggested framework. According to the study, due to the nonaccessibility of a steady and dependable technique for determining contingency along with a suitable application of statistical approach often leads to project time, cost and resources overruns, which frequently prompts delay in projects.

The allocation of contingency is a challenging assignment and tricky decision. According to the study conducted by Cioffi et al., (2007), in the majority of the studied construction projects, contingency allocation process was irregular and subjective. The study had utilised a mathematical model in particular binomial distribution with a probability equal to the project risks' average probability. In light of the accumulation of different project risks and its impacts were then summed over the predetermined number of risks, prompting reasonable possibility contingency budget. Paper additionally mentions that technique or model preferred for contingency estimation should beat disorders of possibility being communicated as a percentage of estimate cost. Generally, it is insufficient aside from it is being connected with some project risk scenarios and its probability whereby the level of cost overrun will not surpass the selected or preferred contingency allowance.

Numerous research studies have been conducted in the area of contingency fund utilisation to address projectspecific risks and uncertainties. According to Alfred, et al., (2010), risk and applicable cost overruns are crucial for construction projects, which are taken care with the assignment of an arbitrary flat percentage of the construction budget as a contingency fund. The study developed a model based on multiple linear regression concepts to estimate suitable contingency reserve for air force construction projects. The suggested model had considered various parameters like the nature of projects, project scope and quality criteria, and bid stage assumptions which were further used in measuring performance metrics and accordingly research framework measured $44 \%$ of actual cost overspending versus the $20 \%$ measured based on the study undertaken. The proposed model provides insight in estimating contingency reserve or provision needed for cost estimation and managing cost in infrastructure projects.

Construction projects' performance differs with and without consideration of contingency. According to Musa et al., (2011) on the study on public and private organisations in Kaduna, Kano, and Abuja, there was a noticeable change among studied projects with and without consideration of contingency based on the precision of estimated cost. The study recommends the application of quantitative risks to improve the accuracy of cost contingency allowance. This observation was further endorsed by Aibinu et al., (2002) during the study on the impacts of delays on project delivery in the Nigerian construction industry. The study inferred that the distribution of contingency allowance based on assumption and perception of risks seems to be insufficient and impractical in most cases. The study further highlights that the possibility of contingency sums 
incorporated into the pre-contract or bid estimate of projects was not sufficient to overcome cost overrun problems happens because of different unexpected situations.

Osipova et al., (2013) in the study has considered two construction projects for studying joint risk management for balancing control and flexibility in managing projects. The study correlated the significance of project operational performances in managing risks and examined the relationship between project control and flexibility oriented risk management strategies. The research proposes joint risk management for assessing project contingency which requires both mechanistic (control-oriented) and organic (flexibility-oriented) management systems in managing unknown risks and uncertainties.

Contingency inclusion should have a definite strategy as, without a laid-down strategy, it is usually being considered based on the subjective manner which dilutes the actual purpose of contingency in construction projects. According to Piero Anticona (2019) study outcomes, a preliminary assessment should be conducted along with the involvement of proposal cell while preparing baseline estimates during project sensitivity analysis. This should help in determining an effective contingency estimation strategy for specific cost drivers and their potential impacts on project performance.

The contingency is a scarce project buffer; hence it should be judiciously spent to accommodate unknown project risks and upholding project performance commitments. Based on the study conducted by Randolph Ruff, et al. (2018) on construction projects, there should be structured contractor contingency provision to distinguish contractor specific risks from client-specific risks, and it must be used to accommodate contractor risks. Moreover, the specific uses of contractor contingency should be well defined to preserve flexibility in its use for unforeseen incidence.

Hence, as per the literature review, most of the study had focused on contingency practices, and issues faced globally in construction projects by construction contractors and clients. However, specifically for Indian companies' scenario, little study has been done in addressing the issues of contingency management in Indian construction projects. Therefore, the current study aims to address specific issues raised in the literature review and attempted to investigate the core issues related to contingency management in Indian construction projects. The literature review aided in identifying research variables, designing a questionnaire survey and selecting archival data from previously completed projects.

\section{Research Methodology}

In the current study; two methods were adopted, the first method was the questionnaire survey, and the second method was the archival database analysis of 50 completed construction projects. The questionnaire survey method was mainly used for gathering required current data, and assessing key aspects and attributes, challenging related ideas provided by literature review. The surveyed construction companies professionals' opinions/observations were measured for various areas/requirements as well as different levels of measurement considered for the study. Archival database for the study was considered from 50 construction projects in India that had been completed between Calendar Year (CY) 2014 to 2019 to check project cost variance by analysing estimated project cost (with and without contingency) and final project cost for assessing contingency effectiveness in overcoming cost overruns problems faced during the execution stage.

\subsection{Sample population}

The sample population of the study included construction companies/contractors, vendors/suppliers, customers and consultants as per the database available on Construction Industry Development Council of India (CIDC Database) . The study had extracted construction companies' details from CIDC database; accordingly, the selection of construction companies was classified into five categories based on construction companies' sectorial presence/nature of the business, annual turnover, employee strength, qualification of project professionals and project experience. The required sample population was drawn from construction companies in the road and highways, thermal and gas-based power plants, bridges and tunnels, airports, metros and other basic infrastructure sectors. The study had focused on category 1, 2 and 3 construction companies as category 4 and 5 was not considered due to its negligible size, inadequate experience in the construction sector and lesser contribution in the Indian construction sector. Details of the study population considered mentioned in Table 1 .

Table 1: Details of sample population

\begin{tabular}{lcccc} 
& Category & Category & Category & Total \\
& $\mathbf{1}$ & $\mathbf{2}$ & $\mathbf{3}$ & \\
\hline Construction & & & & \\
Companies & 137 & 122 & 76 & 335 \\
Percentage & $41 \%$ & $36 \%$ & $23 \%$ & $100 \%$ \\
\hline
\end{tabular}

\subsection{Sampling technique and frame}

The study had preferred a mixture of unbiased sampling and snowball sampling due to difficulty in identifying the exact number of Indian construction companies relevant to the study. The snowball sampling technique is a non-probability method, and that is usually used in research when the elements of a survey population are difficult to trace. Unbiased sampling helped in covering the required sample population without overlooking any construction companies as per filter criteria from the CIDC database. In the current study, the actual number of construction companies could not be established due to the presence of organised and unorganised players; hence a snowball sample was adopted which helped the study in obtaining the required data of Indian construction companies as per selection criteria. Therefore, considering the vast number of construction companies as per CIDC database, study had focused on categories 1,2 and 3 as it was difficult to capture relevant study data from all the construction companies, hence snowball sampling was necessary to make the survey possible. 
Considering the study on sampling frame by Ankrah (2007) and probable respondents for the survey, the sample population was adopted from CIDC database, which provided required construction companies details. Further to establish a suitable size for the sample as per the study observations undertaken by Salant and Dillman (1994), the preferable sample size for the $95 \%$ confidence level should be considered for the study. However, considering the possibilities of low response and difficult to obtain data from targeted 100 companies, ideal sample size considered for the survey was 335 construction companies which were $29.85 \%$ and within the range of 20 to $30 \%$ (as per the construction study conducted by Takim, Akintoye and Kelly, 2003). Table-2 below summarises questionnaire survey statistics

Table 2: Questionnaire survey statistics

\begin{tabular}{lccc}
\hline $\begin{array}{l}\text { Surveyed } \\
\text { Project } \\
\text { Companies }\end{array}$ & $\begin{array}{l}\text { Number of } \\
\text { Questionnaires by Surveyed } \\
\text { Circulated }\end{array}$ & $\begin{array}{c}\text { Not Responded } \\
\text { Companies }\end{array}$ & $\begin{array}{c}\text { Responded } \\
\text { in \% }\end{array}$ \\
\hline $\begin{array}{c}\text { Contractors } \\
\text { Vendors/ }\end{array}$ & 145 & 97 & 33.1 \\
$\begin{array}{c}\text { Suppliers } \\
\text { Customers }\end{array}$ & 115 & 78 & 32.17 \\
Consultants & 32 & 31 & 26.19 \\
\hline \multicolumn{1}{c}{ Total } & 335 & 29 & 12.12 \\
\hline
\end{tabular}

Table- 3 shows the demographic profile of respondents which reveals that in terms of academic qualification of surveyed professionals $80 \%$ were graduates out of which $56 \%$ were engineering graduates which bolstered the affirmation that surveyed professionals had the required academic credentials for participating in the survey. Moreover, considering survey requirements of requisite project experience, $86 \%$ had project experience between 10 and 20 years in construction projects. This displays that surveyed professionals were knowledgeable about the construction industry and capable of answering the questions as per questionnaire and study requirements.

Table 3: Demographic profile of surveyed respondents

Category Classification Frequency Percentage

\begin{tabular}{cccc}
\hline & Contractor & 41 & 41 \\
Type of & Vendor/ & 33 & 33 \\
Project & Supplier & & \\
Companies & Customer & 14 & 14 \\
& Consultant & 12 & 12 \\
\hline & Diploma & 7 & 7 \\
& B.E/B.Tech & 56 & 56 \\
Academic & Other & 24 & 24 \\
Qualification & Graduates & & \\
& PG/PhD & 13 & 13 \\
\hline & $0-9$ & 6 & 6 \\
& $15-$ Oct & 52 & 52 \\
Project & $15-20$ & 34 & 34 \\
Experience & 21 and Above & 8 & 8 \\
& Total & $\mathbf{1 0 0}$ & $\mathbf{1 0 0}$ \\
\hline
\end{tabular}

\subsection{Data collection methods}

\subsubsection{Questionnaire survey}

A previous literature review (as mentioned in the literature review section) resulted in identifying various factors for the study. The main intent of using a questionnaire survey was to check the current scenario of contingency management, understanding contingency estimating methods, utilisation of contingency, bottlenecks along with areas of improvement for contingency management in surveyed Indian construction companies. The questionnaire comprises two parts (refer Appendix for details); the first part was used to cover required demographic information of respondents like name, type of project companies, academic qualifications, and project experience. At the same time, the second part focused on 12 relevant questions to gather required details related to areas/requirements as well as different levels of measurement considered for the study. Each question had four options for the main consistency of the survey's responses.

For questions no. 3 to 12 in the questionnaire; against the selected option, the response had been captured on a five-point "Likert Scale or Rating Scale" extending from 1 to 5 , where 1 denotes 'Strongly Disagree or Never' and 5 denotes 'Strongly Agree or Very Frequent'. Furthermore, various factors that were considered in the design of the questionnaire included the following;

a. The complexity of Indian construction projects;

b. The simplicity of collecting information from respondents and their experience of handling contingency and;

c. Collecting maximum possible relevant data for analysing and validating various research objectives as mentioned.

Accordingly, the questionnaire was prepared after benchmarking with similar studies conducted around the world. Questionnaire distributions, as well as personal interviews, were conducted among 335 construction companies to achieve the desired aim of the study.

The Questions in questionnaire survey were structured with a purpose to test various contingency management parameters such as:

a. Objectives and strategies of contingency,

b. Factors that determine the percentage addition of contingency,

c. Involvement of key stakeholders,

d. Utilisation and exclusion of contingency,

e. Techniques of determining contingency,

f. Bottlenecks in contingency management,

g. Areas of improvement for efficient contingency management.

The study had attempted to reduce the ambiguities of terminology and content of questions; accordingly, the questionnaire format was reviewed and validated by academic and industry experts. This helped in aligning questionnaires with the Indian construction industry scenario and accordingly preliminary list of factors along with probable questions were reframed. Based on experts, valuable observations and suggestions suitable modifications in the questions were incorporated in terms of framing of questions, logic, and selection of options for each question along with rearrangement of orders suitably. Experts again reviewed the revised questionnaire 
and found that it provides the required clarity and captures relevant information for the study.

\subsubsection{Archival Database}

To assess the effectiveness of contingency utilisation as one of the research objectives, the archival database of 50 Indian construction projects completed between CY 2014 to 2019 was considered to obtain project specifics data such as estimated project cost, actual project cost, and contingency provision. The main intention of studying the archival database was to identify and assess contingency provision in estimated cost along with its effectiveness in overcoming cost overrun problems during the execution stage. Research parameters considered for evaluation were Project Estimated or Scheduled Cost (SC), Project Actual Cost (AC) and Contingency Provision.

The Selection pool of 50 Indian construction projects for the archival database was considered based on the following criteria;

- Domain/ Segment Presence

- Project value in INR billion

- Construction project cost in \% of total revenue

- Market share/position in the Infrastructure domain

- Application of contingency reserve

In terms of selected projects' infrastructure sector presence, comprised of Roads and Highways (total no of companies- 15), Power (15), Railways and Metros (10), Urban Infrastructures (5) and Real Estate (5) situated in different parts of India. The size of the companies in terms of turnover (revenue) ranged from US\$ 7.2 million to greater than US\$ 143 million (considering INR to US\$ conversation rate of INR $70=1 \mathrm{US} \$$ at the end of $31 \mathrm{st}$ March 2019) as shown in Figure 1. Construction project selection was made to check the level of project performance with and without consideration of contingency.

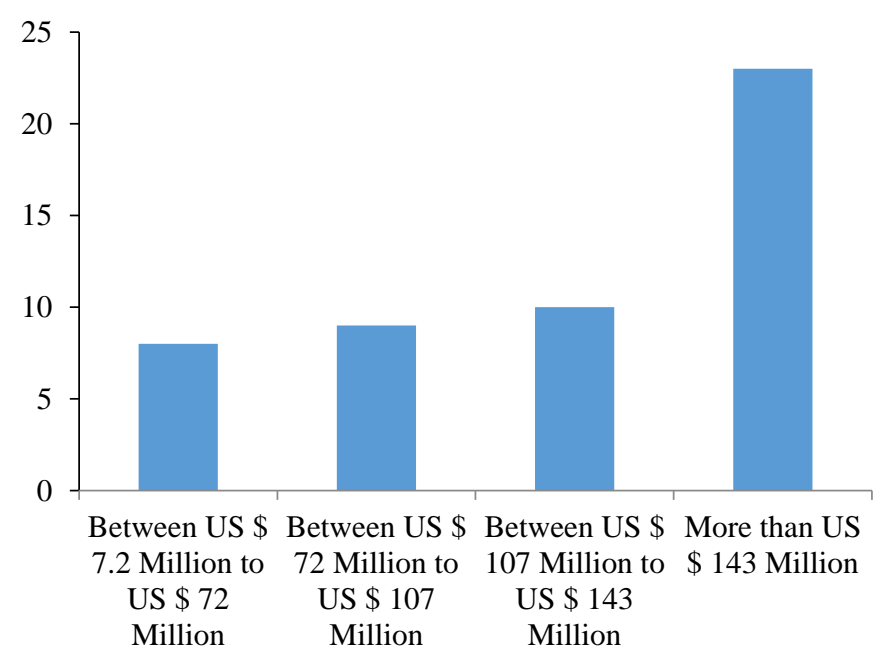

Figure 1: Indian construction projects' size in terms of turnover (revenue in US \$)

\subsection{Data Analysis tools}

The data obtained from the questionnaire survey were analysed using the SPSS (Statistical Package for Social Science) simple statistical tools that included RII (Relative Importance Index), mean, standard deviation and ranking methods. Survey data were captured against various parameters or options which were further analysed using percentage, which helps in ranking of selected options exercised by respondents. Relative Importance Index (RII) was considered for two reasons; first for assigning ranking for option opted by survey respondents and second was to measure the impact of different factors and options selected by the respondents. A decision regarding rank for the opted option was taken using RII, where the highest RII for option considered first ranked and accordingly in descending orders for other rankings as per the study conducted by Nurudeen (2002). RII was calculated based on the adopted 5-point Likert scale by using the following formula.

$$
R I I=\frac{5 n_{5}+4 n_{4}+3 n_{3}+2 n_{2}+1 n_{1}}{5\left(n_{5}+n_{4}+n_{3}+n_{2}+n_{1}\right)}
$$

Where: $n_{5}=$ Strongly Agree, $n_{4}=$ Agree, $n_{3}=$ Neither Agree or Disagree, $n_{2}=$ Disagree, $n_{1}=$ Strongly Disagree and $N=$ Total number of respondents $\left(n_{5}+n_{4}+n_{3}+n_{2}+\right.$ $\left.n_{1}\right)$

Similarly, a mean score was used to measure intermediate numerical values to respondents score. While standard deviation was used to measure the differences of each observation from the mean. Simple statistical tools helped in ranking the option against each question for better analysis of questionnaire survey results.

For assessing the effectiveness of contingency utilisation, cost variance (CV) was computed based on actual cost and scheduled or estimated cost captured from the archival database of 50 Indian construction projects. Data analysis intend to captured relevant results which were aligned with research objectives to obtained required research findings and accordingly, conclusion and recommendation have been made.

\section{Results and Discussion of Findings}

The Survey findings and data interpretation of 100 respondents, along with archival data analysis of 50 Indian construction projects are outlined below.

\subsection{Questionnaire survey findings}

This section depicts result interpretations of the questionnaire survey data collected and its research findings as underneath.

Construction Cost in the percentage of Project

Budget for Indian Construction Companies

As mentioned in the table-4, based on RII, mean and SD (Standard Deviation) scores, construction companies spend $85 \%$ to $90 \%$ of project budget ranked first and $80 \%$ to $85 \%$ of project budget ranked second. Therefore, the majority of surveyed Indian construction companies spend almost $80 \%$ to $90 \%$ of the project budget towards construction material, sub-contracting, payroll, overheads and facilities expenses. Hence, an extensive portion of funds being spent towards capital works and therefore, any escalation in construction costs and project resource prices can significantly impact construction projects' operational and financial performance. The study findings are aligned with outcomes of Baccarini, (2004) which shows that suitable contingency provision can cushion 
Indian construction companies in overcoming cost overrun problems.

Table 4: Construction cost in \% of project budget

\begin{tabular}{lcccc}
\hline Parameter & RII* & Mean & SD** & Rank \\
\hline $85 \%$ to $90 \%$ & 0.238 & 8.8 & 3.42 & 1 \\
$80 \%$ to $85 \%$ & 0.234 & 7.6 & 1.82 & 2 \\
$75 \%$ to $80 \%$ & 0.088 & 3 & 0.71 & 3 \\
Less than $75 \%$ & 0.024 & 0.6 & 0.55 & 4 \\
\hline * Relative Importance Index (RII) and $* *$ Standard Deviation \\
(SD)
\end{tabular}

\subsection{Contingency consideration concerning estimated cost}

The Contingency provision for project estimated cost is a tricky decision for construction companies as too low or a high level of a contingency can create cost overruns or over budget problems. Hence, optimum consideration of contingency concerning estimated cost baseline (CBL) has been a crucial aspect as it impacts project performance of the current project and also decides fortune for future projects.

Table-5 shows that contingency consideration of 0 to $5 \%$ with respect to estimated cost had RII of 0.554 , mean score of 14 and SD of 10.02 accordingly ranked first. While options 6 to $10 \%$ had an RII of 0.198 , a mean score of 5 and an SD of 3.58 ranked second. Likewise, option 11 to $15 \%$ based on RII, mean and SD score ranked third. Study findings are aligned with the previous studies of Amade et al. (2014) which illustrates that contingency is the inadequate provision of the estimated cost for overcoming cost overrun problems during execution.

Table 5: \% of Contingency with respect to estimated cost

\begin{tabular}{ccccc}
\hline Parameter & RII & Mean & SD & Rank \\
\hline 0 to $5 \%$ & 0.554 & 14 & 10.02 & 1 \\
6 to $10 \%$ & 0.198 & 5 & 3.58 & 2 \\
11 to $15 \%$ & 0.038 & 1 & 0.63 & 3 \\
More than $15 \%$ & 0 & 0 & 0 & 4 \\
\hline
\end{tabular}

\subsection{The objective of contingency management}

Table 6: The objective of contingency management

\section{Parameter}

RII Mean SD Rank

\begin{tabular}{|c|c|c|c|c|}
\hline $\begin{array}{l}\text { Safeguarding optimum project } \\
\text { cost as per project bidding price }\end{array}$ & 0.454 & 11 & 11.6 & 1 \\
\hline $\begin{array}{l}\text { Keeping project cost within } \\
\text { PMB } \\
\text { Measurement } \\
\text { (Performance } \\
\text { throughout project tenure }\end{array}$ & 0.2 & 5 & 4.47 & 2 \\
\hline $\begin{array}{l}\text { Contributing to the overall } \\
\text { project firms objective of } \\
\text { managing and mitigating } \\
\text { unforeseen risk exposure }\end{array}$ & 0.0 & 2 & 1.73 & 4 \\
\hline $\begin{array}{l}\text { Ensuring meeting project cost } \\
\text { and profit target }\end{array}$ & 0.08 & 2 & 2.12 & 3 \\
\hline
\end{tabular}

Table 6 depicts the objective of contingency management as preferred by construction companies. Data analysis shows that safeguarding optimum project cost as per project bidding price was the prime objective of contingency with RII of 0.454 , mean score of 11 , SD of 11.6 ranked first. This was followed by keeping the cost within CBL (Cost Base Line) throughout project tenure and contributing to the overall project firms objective of managing and mitigating unforeseen risk exposure and ensuring meeting project cost and profit target were having RII of 0.2, 0.086 and 0.078 mean score of 5, 2, 2 and SD of 4.47, 2.12, 1.73 respectively had been ranked second, third and fourth respectively. Study findings are aligned with observations of Baccarini et al. (2003) which established that safeguarding project cost was the prime objective of Indian construction companies.

\subsection{Involvement of key stakeholders in contingency management}

The results suggest that optimum estimation, along with an efficient implementation of a contingency, depends on the involvement of key stakeholders of construction projects. The results summarised in Table 7 shows that the project proposal cell was the preferable stakeholder in a contingency management process having RR of 0.354 , a mean score of $9, \mathrm{SD}$ of 7.11 and ranked first. While other options based on their RII, mean and SD score ranked lower. These findings are aligned with remarks by Anticona (2019) that the proposal cell is the key stakeholder in contingency management due to their involvement during the initiation stage and their influence in the decision-making process.

Table 7: Involvement of key stakeholders in contingency management

\begin{tabular}{lcccc}
\hline \multicolumn{1}{c}{ Parameter } & RII & Mean & SD & Rank \\
\hline Project Proposal Cell & 0.354 & 9 & 7.11 & 1 \\
Project Planning Cell & 0.174 & 5 & 2.35 & 2 \\
Project Execution Cell & 0.156 & 4 & 3.46 & 3 \\
Project Finance and Accounts & 0.086 & 2 & 2.12 & 4 \\
Cell & & & \\
\hline
\end{tabular}

\subsection{Selection criteria for contingency}

The study seems to recommend that for effective delivery of operational and financial performance, it is paramount to have logical selection criteria for a contingency.

Table 8: Selection criteria for contingency

\begin{tabular}{|c|c|c|c|c|}
\hline Parameter & RII & Mean & SD & Rank \\
\hline $\begin{array}{l}\text { Assumption based on the } \\
\text { addition of the sum of } \\
\text { considering formal risk } \\
\text { analysis of the project }\end{array}$ & 0.272 & 7 & 4.95 & 1 \\
\hline $\begin{array}{l}\text { Based on the addition of sum } \\
\text { reflecting in-built observation } \\
\text { of risk }\end{array}$ & 0.186 & 5 & 3.24 & 3 \\
\hline $\begin{array}{l}\text { As per standard } \% \text { laid down } \\
\text { under S.O.Ps } * *\end{array}$ & 0.218 & 6 & 3.39 & 2 \\
\hline $\begin{array}{l}\text { Suitable advice from project } \\
\text { proposal or estimation cell }\end{array}$ & 0.07 & 2 & 1 & 4 \\
\hline
\end{tabular}

Table 8 shows that contingency was selected on an assumption basis was having RII of 0.272 , a mean score of 7 and SD of 4.95 was ranked first. Other options based on their RII, mean and SD score ranked in descending manner. 


\subsection{Factors that determine the percentage addition of contingency to the estimated cost}

The study sought to find out the factors that establish the percentage addition of a contingency to the estimated cost. This question elucidated a mixed response from respondents. Table 9 indicates that the amount and volume of project work and level of project rework had an RII of 0.296 and 0.258 ; a mean score of 8 and 7 with SD of 4.69 and 4 ranked first and second. Meanwhile, project location and project-specific factors were ranked third and fourth as per RII, mean and SD scores. The study findings are aligned with outcomes of previous research by Lorance et al. (2001) and Alfred et al. (2010) which indicate that opinion was divided among construction companies regarding consideration of factors that determine the percentage addition of contingency to the estimated cost. .

Table 9: Factors that determine the percentage addition of contingency to estimated cost

\begin{tabular}{lcccc}
\hline \multicolumn{1}{c}{ Parameter } & RII & Mean & SD & Rank \\
\hline $\begin{array}{l}\text { Project location and } \\
\text { geographical conditions }\end{array}$ & 0.132 & 3.4 & 2.4 & 3 \\
$\begin{array}{l}\text { Amount and volume of project } \\
\text { work }\end{array}$ & 0.296 & 8 & 4.69 & 1 \\
$\begin{array}{l}\text { Level of project rework } \\
\begin{array}{l}\text { Project specific factors like the } \\
\text { type of client and duration }\end{array}\end{array}$ & 0.258 & 7 & 4 & 2 \\
\hline
\end{tabular}

\subsection{Utilisation of contingency}

Contingency if it is fully utilised or partially utilised becomes an interesting investigating issue since; based on its current utilisation, its provision for the next project may be aligned appropriately. The findings in this category are summarised in Table 10. The results reveal that $45 \%$ of companies rank contingency for accommodating cost overruns during the execution stage first with RII of 0.338, mean score of 9 and SD of 5.52. This is followed by errors/omissions in the estimation stage, with a mean score of 7 and SD of 4.06 . At the same time, mitigating project risks and uncertainties and fulfilling project commitments are ranked third and fourth with mean scores of 2, 2 and SD of 1.22, 1, respectively. These findings are aligned with those of earlier observations by AACE (2008) and Hart (2007) which shows that contingency reserve was utilised in an unplanned manner based on a subjective approach in surveyed Indian construction companies.

Table 10: Utilisation of contingency

\begin{tabular}{|c|c|c|c|c|}
\hline Parameter & RII & Mean & SD & Rank \\
\hline $\begin{array}{l}\text { To accommodate } \\
\text { errors/omissions in the } \\
\text { estimation stage. }\end{array}$ & 0.26 & 7 & 4.06 & 2 \\
\hline $\begin{array}{l}\text { To accommodate higher } \\
\text { project spending due to cost } \\
\text { overruns }\end{array}$ & 0.338 & 9 & 5.52 & 1 \\
\hline $\begin{array}{l}\text { To mitigate project risk and } \\
\text { uncertainties }\end{array}$ & 0.072 & 2 & 1 & 4 \\
\hline $\begin{array}{l}\text { To fulfil project commitments } \\
\text { in terms of schedule, quality } \\
\text { and performance }\end{array}$ & 0.072 & 2 & 1.22 & 3 \\
\hline
\end{tabular}

\subsection{Exclusion of contingency}

The current study has identified another interesting aspect to be examined, i.e. the exclusion of contingency as clear 'NO' in terms of its utilisation. The findings of this survey as indicated in Table 11 shows that contingency was not preferable for any change in project scope (mean score of 11 and SD of 9.67) and ranked first followed by project transferred risk, unexpected work stoppage and cost variations ranked second, third and fourth respectively based on its mean and SD scores. These research findings are aligned with recommendations by AACE (2008) for the exclusions of contingency and prevention of contingency mistreatment.

Table 11: Exclusion of contingency

\begin{tabular}{|c|c|c|c|c|}
\hline Parameter & RII & Mean & SD & Rank \\
\hline Project scope change & 0.44 & 11 & 9.67 & 1 \\
\hline $\begin{array}{l}\text { Project unexpected work } \\
\text { stoppage due to a strike or } \\
\text { lockout. }\end{array}$ & 0.128 & 3.4 & 2.07 & 3 \\
\hline $\begin{array}{l}\text { Project cost variations due to } \\
\text { inflation and currency } \\
\text { fluctuations }\end{array}$ & 0.068 & 3 & 0.71 & 4 \\
\hline $\begin{array}{l}\text { Project transferred risk or } \\
\text { risk being taken care of by } \\
\text { project insurance }\end{array}$ & 0.156 & 4 & 3.46 & 2 \\
\hline
\end{tabular}

\subsection{Techniques of determining a contingency}

The technique for determining contingency was investigated in this study. The survey asked respondents to specify the preferred technique for a contingency estimation. Table 12 highlights the techniques of determining contingency preferred by construction companies. The results indicate that the traditional percentage rate method based on historical performance (RII of 0.492 , mean score of 12 and SD of 11.75) was ranked first while the project scheduling techniques (mean score of 4 and SD of 2.74) was ranked second. The findings are of concern because the traditional percentage rate method based on historical performance has several flaws which limit the effectiveness of contingency reserve in Indian construction companies.

Table 12: Techniques of determining contingency

\begin{tabular}{|c|c|c|c|c|}
\hline Parameter & RII & Mean & SD & Rank \\
\hline $\begin{array}{l}\text { Traditional Percentage rate } \\
\text { based on the historical project } \\
\text { performance }\end{array}$ & 0. & 12 & 11.75 & 1 \\
\hline $\begin{array}{l}\text { Statistical Methods like } \\
\text { Regression Analysis and } \\
\text { Monte Carlo Simulation }\end{array}$ & 0.128 & 3.7 & 2.07 & 3 \\
\hline $\begin{array}{l}\text { Project Risk Analysis and } \\
\text { suggested outcome }\end{array}$ & 0.154 & 4 & 2.74 & 2 \\
\hline $\begin{array}{l}\text { Project Scheduling } \\
\text { Techniques like PERT and } \\
\text { CPM }\end{array}$ & 0.038 & 1 & 0.71 & 4 \\
\hline
\end{tabular}

Result findings are aligned with the findings of Baccarini (2004 and 2005) and Khalafallah et al. (2005) which demonstrates that contingency estimation performed based on the conventional methods like 
perception, historical information and expert advice was arbitrary and illogical. The leading cause of cost overrun on construction projects.

\subsection{Bottlenecks in Contingency Management}

The research aimed to explore various bottlenecks in contingency management for Indian construction companies. Based on survey findings and analysis as indicated in Table 13, the lack of clarity (RII of 0.258 , mean score of 7 and SD of 5) was ranked first while ignorance or lack of clarity about S.O.Ps/process (RII of 0.23 , mean score of 6 and SD of 4.36) was ranked second. Likewise, lack of coordination and non-availability of appropriate data was ranked third and fourth, respectively. Overall data analysis shows that there was no clear consensus about the main bottlenecks in contingency management among the 50 Indian construction companies surveyed.

Table 13: Bottlenecks in Contingency Management

\begin{tabular}{lcccc}
\hline \multicolumn{1}{c}{ Parameter } & RII & Mean & SD & Rank \\
\hline $\begin{array}{l}\text { Lack of clarity about the } \\
\text { construction project's } \\
\text { objective on contingency } \\
\text { management }\end{array}$ & 0.258 & 7 & 5 & 1 \\
$\begin{array}{l}\text { Ignorance or lack of clarity } \\
\text { about S.O.Ps/process of } \\
\text { contingency management }\end{array}$ & 0.23 & 6 & 4.36 & 2 \\
$\begin{array}{l}\text { Lack of coordination } \\
\text { between proposal and } \\
\text { planning cell (in terms of } \\
\text { proper estimation) and } \\
\text { execution cell (in terms of } \\
\text { effective utilisation) }\end{array}$ & 0.164 & 4 & 4.12 & 3 \\
$\begin{array}{l}\text { Non-availability of proper } \\
\text { data and poor understanding } \\
\text { of contingency mechanism } \\
\text { and instruments }\end{array}$ & 0.132 & 3.4 & 2.51 & 4 \\
\hline
\end{tabular}

\subsection{Strategies for forecasting Contingency}

Table 14: Strategies for forecasting Contingency

\begin{tabular}{|c|c|c|c|c|}
\hline Parameter & RII & Mean & SD & Rank \\
\hline $\begin{array}{l}\text { At the time of submitting } \\
\text { project bid }\end{array}$ & 0.338 & 9 & 5.22 & 1 \\
\hline $\begin{array}{l}\text { At the time of receiving } \\
\text { project orders from } \\
\text { customers }\end{array}$ & 0.24 & 6 & 4.9 & 2 \\
\hline $\begin{array}{l}\text { At the time of project } \\
\text { execution and occurrence } \\
\text { of cost overruns }\end{array}$ & 0.198 & 5 & 3.87 & 3 \\
\hline $\begin{array}{l}\text { No fixed timeline and } \\
\text { forecasting strategy }\end{array}$ & 0.068 & 2 & 0.71 & 4 \\
\hline
\end{tabular}

One of the objectives of the research was to identify the strategies for forecasting contingency in Indian construction companies. Table 14 shows that at the time of submitting project bid (RII of 0.338 , mean score of 9 , $\mathrm{SD}$ of 5.22), at the time of receiving orders from customers (RII of 0.24 , mean score of $6, \mathrm{SD}$ of 4.9 ), at the time of project execution and occurrence of cost overruns (RII of 0.198 , mean score of $5, \mathrm{SD}$ of 3.87 ) and no fixed timeline and forecasting strategy (RII of 0.068 , mean score of 2, SD of 0.71) were ranked first, second, third and fourth respectively.

The results are aligned with those of previous findings by Aibinu et al. (2002) which found that there was no well-placed strategy for forecasting contingency in Indian construction companies. The same could be a dampener for contingency objectives in addressing undefined project risk and cost overrun problems in Indian construction companies.

\subsection{Suggested Areas of improvement for efficient Contingency Management}

An important objective of the current study was to explore areas of improvement for efficient contingency management on construction projects. The survey findings concerning this enquiry shown in Table 15 indicates a mixed preference of surveyed professionals. The following options: identification of project contingency and execution strategy during project bid stage, project contingency management awareness, aligning of proposal and planning cell and execution cell activities and availability and access of project contingency database are ranked in descending order based on RII, mean score and SD details.

Table 15: Areas of Improvement for Efficient Contingency Management

\begin{tabular}{|c|c|c|c|c|}
\hline Parameter & RII & Mean & SD & Rank \\
\hline \multicolumn{5}{|l|}{ Identification of Project } \\
\hline Contingency and execution & 0.26 & 7 & 4.3 & 1 \\
\hline strategy during project bid stage & 4 & & & \\
\hline \multicolumn{5}{|l|}{ Project Contingency } \\
\hline Management awareness in terms & & & & \\
\hline $\begin{array}{l}\text { of S.O.Ps, process and role } \\
\text { clarity among project }\end{array}$ & 0.24 & 6 & $\begin{array}{c}3.0 \\
7\end{array}$ & 2 \\
\hline professionals & 6 & & & \\
\hline \multicolumn{5}{|l|}{ Aligning of Proposal and } \\
\hline $\begin{array}{l}\text { Planning Cell (in terms of } \\
\text { proper estimation) and }\end{array}$ & & 5 & 4.3 & 3 \\
\hline Execution cell (in terms of & 0.20 & & 6 & \\
\hline effective utilisation) activities & 2 & & & \\
\hline Availability and access to & & & & \\
\hline Project Contingency & 0.07 & 2 & 1.2 & 4 \\
\hline management database & 4 & & & \\
\hline
\end{tabular}

\subsection{Archival Data Analysis of 50 Indian Construction Projects}

This section displays the interpretations of archival data based on the analysis of data collected from 50 Indian construction projects.

The study established that there is a disconnection between management expectations and opinions of the respondents surveyed through the questionnaire. Therefore, it is prudent to measure quantitatively further the effectiveness of contingency utilisation expected by the construction companies' management in overcoming cost overruns problems during the execution stage of the studied archival database of 50 Indian construction projects completed between 2014 to 2019.

The archived database was analysed statistically by using the scatter plot diagram. The primary intent of using 
the scatter plot diagram was to segregate outlier categories of construction projects from the pool of construction projects based on selected criteria like project value in INR billion, construction project cost in \% of total revenue and application of a contingency reserve. This resulted in removing five construction projects out of 55 selected initially, which yielded 50 projects for the study.

The next step was to check the project cost variation (CV) considering various types of project fluctuations which were computed by considering estimated project cost (with and without contingency) and final project cost.

From the archival database, the estimated project cost and the final project cost were used in determining cost variance (which is the difference between estimated or scheduled project cost and final actual cost) and depicted in Table 16.

Table 16: Cost Variance (in terms of size of the projects) of 50 Indian Construction Projects

\begin{tabular}{|c|c|c|c|c|c|c|c|c|c|c|}
\hline \multirow{2}{*}{$\begin{array}{l}\text { Cost Variance in \% } \\
\left(\mathrm{CV}=\mathrm{SC}^{*}-\mathrm{AC}^{* *}\right)\end{array}$} & \multicolumn{2}{|c|}{$\begin{array}{c}\text { Project Size in } \\
\text { INR } 500 \text { million to } \\
5 \text { billion }\end{array}$} & \multicolumn{2}{|c|}{$\begin{array}{c}\text { Project Size in } \\
\text { INR } 5 \text { billion to } 7.5 \\
\text { billion }\end{array}$} & \multicolumn{2}{|c|}{$\begin{array}{c}\text { Project Size in } \\
\text { INR } 7.55 \text { billion to } \\
10 \text { billion }\end{array}$} & \multicolumn{2}{|c|}{$\begin{array}{l}\text { Project Size in } \\
\text { INR }>10 \text { billion }\end{array}$} & \multicolumn{2}{|c|}{$\begin{array}{l}\text { Summary of } \\
\text { Projects }\end{array}$} \\
\hline & $\begin{array}{c}\text { No of } \\
\text { Projects }\end{array}$ & $\%$ wise & $\begin{array}{c}\text { No of } \\
\text { Projects }\end{array}$ & $\%$ wise & $\begin{array}{c}\text { No of } \\
\text { Projects }\end{array}$ & $\%$ wise & $\begin{array}{c}\text { No of } \\
\text { Projects }\end{array}$ & $\%$ wise & $\begin{array}{l}\text { No } \\
\text { wise }\end{array}$ & $\begin{array}{c}\% \\
\text { wise }\end{array}$ \\
\hline$(>5$ but $<10)$ & 1 & 20 & 1 & 12.5 & 1 & 10 & 3 & 11.11 & 6 & 12 \\
\hline$(<5)$ & 1 & 20 & 2 & 25.0 & 2 & 20 & 7 & 25.93 & 12 & 24 \\
\hline 0 & 0 & 00 & 1 & 12.5 & 2 & 20 & 5 & 18.52 & 8 & 16 \\
\hline$<5$ & 2 & 40 & 2 & 25.0 & 4 & 40 & 9 & 33.33 & 17 & 34 \\
\hline$>5$ but $<10$ & 1 & 20 & 2 & 25.0 & 1 & 10 & 3 & 11.11 & 7 & 14 \\
\hline Total & 5 & 100 & 8 & 100 & 10 & 100 & 27 & 100 & 50 & 100 \\
\hline
\end{tabular}

* Scheduled Cost and ** Actual Cost

Table 16 shows that $12(24 \%)$ of the completed construction projects were having negative CV (Cost Variance $=$ Scheduled Cost - Actual Cost) up to 5\% which includes seven projects valued at more than INR 10 billion, and five projects valued between INR 500 million to less than INR 10 billion. Similarly, in six (12\%) projects were having a negative $\mathrm{CV}$ between $5 \%$ to $10 \%$ out of which three projects were valued at more than INR 10 billion and another three projects were valued between INR 500 million to less than INR 10 billion.

One of the observations for this outcome is that project estimators might have not thoroughly carried out a risk analysis of small and medium-size projects which might have resulted in subjective arrival of contingency provision. Further, the result suggests that 37 (74\%) of construction projects have their cost variation within the range of $\pm 5 \%$ means the estimated cost was within $\pm 5 \%$ of the actual cost. Finally, 18 (36\%) construction projects had negative cost variation between $0 \%$ to $10 \%$ out of which ten projects were valued at more than INR 10 billion which might be due to various reasons like inadequate planning and budgeting, improper project risk analysis and inefficient project execution.

Table 17: Cost Variance (with and without contingency) of 50 Indian Construction Projects

\begin{tabular}{cccc}
$\begin{array}{c}\text { Cost Variance } \\
\text { in \% }\end{array}$ & $\begin{array}{c}\text { No of Projects } \\
\text { without } \\
\text { Contingency }\end{array}$ & $\begin{array}{c}\text { No of } \\
\text { Projects with } \\
\text { Contingency }\end{array}$ & $\begin{array}{c}\text { Total } \\
\text { no of } \\
\text { Projects }\end{array}$ \\
\hline $\begin{array}{c}\text { P } \mathbf{A C} \text { - A }) \\
\text { Cut }<10)\end{array}$ & 8 & 6 & -2 \\
$(<5)$ & 9 & 12 & 3 \\
0 & 0 & 8 & 8 \\
$<5$ & 18 & 17 & -1 \\
$>5$ but $<10$ & 15 & 7 & -8 \\
Total & $\mathbf{5 0}$ & $\mathbf{5 0}$ & $\mathbf{0}$ \\
\hline
\end{tabular}

The next analysis carried out was on the utilisation of contingency (if any), and its impact on project performance in the 50 Indian construction projects studied. The results obtained are outlined in Table 17. As per Table 16, 33 projects $(66 \%)$ are over-budgeted while with consideration of contingency 24 projects resulted in cost overrun. The archival data analysis findings are aligned with the outcomes suggested by Musa et al. (2011), which concludes that contingency consideration was effective in overcoming cost overspending issues in nine out of 50 projects studied.

\section{Conclusions}

The contingency is a provision for Indian construction companies to safeguard project budget against any sudden upswing or overspend which can adversely affect the operational and financial performance of construction projects. The study focused on Indian construction companies to assess the current state; the issues faced in contingency management along with evaluating the effectiveness of contingency utilisation in overcoming cost overrun problems.

The study used structured questionnaires to gather required data along with archival database analysis of 50 Indian construction projects completed between 2014 to 2019. Demographic details of the respondents indicate that $86 \%$ had between 10 and 20 years of experience in handling various infrastructure projects. This suggests that surveyed professionals have the requisite knowledge and could provide vital information in response to the questionnaire and study requirements. Data analysis was undertaken using the SPSS (Statistical Package for Social Science) simple statistical tools that included RII (Relative Importance Index), mean, standard deviation and ranking methods.

Based on the findings obtained from the survey and archival database analysis of Indian construction companies (as outlined in the previous section), the study concludes as follows. 
- The prime objective of contingency management was to safeguard optimum project cost and keeping project costs within cost baseline.

- Contingency was utilised largely in an unplanned mode and having undefined strategies for its forecasting.

- Contingency was not utilised predominantly for project scope change and project transferred risk.

- Project proposal cell and project planning cell were the key stakeholders in the contingency management process.

- In terms of key bottlenecks in contingency management, result analysis reveals that lack of clarity, S.O.Ps, poor coordination among project stakeholders and unavailability of accurate project data are bottlenecks.

- The study further established that there was no proven strategy for forecasting contingency in Indian construction projects. Based on result outcomes, it is evident that forecasting of contingency varies from bid submission time to construction project execution time along with cost overruns occurrences.

- It emerged that project uncertainties prevailed continuously throughout the project life cycle, commencing from the project initiation stage and continuing up to project closeout stage.

- The factor that establishes the percentage addition of contingency to estimated cost was found to depend on project location and geographical conditions to amount and volume of project work, level of project rework and project-specific factors like the type of client, scope clarity and duration-suggesting that contingency addition to estimated cost depends on project-specific factors.

- It also emerged that the majority of Indian construction companies preferred the traditional percentage method for estimating contingency of up to $10 \%$ of the estimated cost based on the historical performance of previous projects without consider ation of project risks. This is despite available evidence that the traditional percentage method has several limitations as it is based on a subjective approach hence unreliable

- Hence, the estimated co ntingency is inadequate and ineffective in overcoming cost overrun problems on Indian construction projects

\section{References}

AACE. (2008). Contingency Estimating General Principles. International Recommended Practice, TCM Framework- Risk Management 40R-08(7.6)

Adnan, Enshassi and Abed, Ayyash. (2014). Factors affecting cost contingency in the construction industry Contractors' perspective, International Journal of Construction Management, https:// 10.1080/15623599.2014.922729

Ahmed, S. EL-Touny., Ahmed, H. Ibrahim., and Mohamed, I. Amer. (2014). Estimating Cost Contingency for Highway Construction Projects Using Analytic
- The problem of cost overrun could have been avoided with the consideration of suitable contingency in the cost baseline during the bidding stage.

- Also, that optimum estimation of contingency helps overcome cost overrun problems in the execution stage.

\section{Recommendations and Direction of Future Research}

The study has tried to fulfil stated objectives based on a detailed analysis of the questionnaire survey and archival database. The interpretation of the results have yielded the following recommendations and direction of future research:

a. Construction companies should have a robust and adequate project budget plan along with appropriate and adequate contingency provision in the estimated cost for achieving project performance and scope commitments.

b. Construction projects should estimate contingency based on scientific techniques like project risk analysis and statistical methods in place of subjective approach (traditional percentage method) for accommodating cost overrun problems.

c. In an ideal scenario, Indian construction projects should consider the inclusion of optimum contingency (preferably up to $10 \%$ ) in estimated cost during the planning stage in the absence of additional projectspecific information.

d. Contingency should be determined based on the amount and volume of work, level of project rework, project location and geographical conditions and other applicable project-specific factors.

e. Need for effective utilisation of a contingency plan by construction companies for defining scenarios to accommodate project unknown risks and cost overrun problems during the execution stage.

f. It is further recommended that future research should focus on contingency management practices adopted by public and private sector infrastructure companies in India. As usual in those companies, the effect of project resource risk analysis is either neglected or inadequately considered in the estimated cost along with improper utilisation of contingency.

Hierarchy Processes. International Journal of Computer Science Issues, 11(issue 6), No 1.

Aibinu, A. A., and Jagboro, G. (2002). The Effects of Construction Delays on Project Delivery in Nigerian Construction Industry. International Journal of Project Management, 20(issue-8), 593-599.

Akinradewo, O. F., and Awodele, O. A. (2016). Evaluation of the Adequacy and Utilisation of Contingency Fund in Building Projects in Nigeria. Open Access Library Journal, 3 http://dx.doi.org/10.4236/oalib.1102925

Akinsola, A.O. (1996). Neural Networks, Model for Predicting Building Projects' Contingency Allowance. 
Proceeding of Association of Researchers in Construction Management Sheffield Hallam University, 1(11), 507516.

Alfred, E. Thal Jr., Jason, J. Cook., and Edward, D. White III. (2010). Estimation of Cost Contingency for Air Force Construction Projects. Journal of Construction Engineering and Management, 136 (11), 1181-1188.

Amade, B., Akpan, E.O.P., and Alajemba, C.C. (2014). Project Cost Contingency in the Nigerian Construction Industry. International Journal of Research in Management, Science and Technology (E-ISSN: 23213264) 2(2).

Ankrah, N. A. (2007). An investigation into the impact of culture on construction project performance. Unpublished $\mathrm{PhD}$ thesis submitted to School of Engineering and the Built Environment, University of Wolverhampton, UK.

Baccarini, D., and Collins, A. (2003). Critical Success Factors for Projects in Brown, A. (ed). Surfing the Waves: Management Challenges; Management Solutions. Proceedings of the 17th ANZAM Conference, 2-5 December, Fremantle, Western Australia.

Baccarini, D. (2004). Accuracy in estimating project cost construction contingency a statistical analysis. Cobra 2004: RICS International Construction Conference, Responding to Change, Headingley Stadium, U.K.

Baccarini, D. (2004). Estimating project cost contingency - a model and exploration of research questions. 20th Annual ARCOM Conference, HeriotWatt University. Association of Researchers in Construction Management, 1, 105-13.

Baccarini, D. (2005). Understanding Project Cost Contingency: A Survey, in Sidwell, A.C. (ed). Proceedings of the Queensland University of Technology Research Week, Brisbane, Qld: Queensland University of Technology.

Bello, W. A., and Odusami, K. T. (2013). Weak management of the predictability of contingency allowance in construction projects in Nigeria, 29th Annual ARCOM Conference, UK, Association of Researchers in Construction Management, 969-978.

Buertey, J. T. I., Abeere-Inga, E., and Adjei, Kumi. T. (2012). Project Cost Contingency Estimation in Ghana: An Integrated Approach. Science Journal of Civil Engineering and Architecture, ISSN: 2276-6332, 2012, https://doi 10.7237/sjcea/214

Cioffi, D. F., and Khamooshi, H. (2007). A practical method for determining project risk contingency budgets. Journal of the Operational Research Society, 565-571.

El-Kholy, A. M. (2015). Predicting Cost Overrun in Construction Projects. International Journal of Construction Engineering and Management, 1(4), 95-105, https:// 10.5923/j.ijcem.20150404.01

Gognaje, Yusuf. Barde. (2015). Evaluation of project risk and the determination of contingency sum for building developments in Nigeria. Ahmadu Bello University Zaria-Nigeria.

Hart, D. H. (2007). Managing the contingency allowance. The AIA Best Practices BP 13.04.05.

Jimoh, A. R. and Shaaba, M. Adama. (2014). Assessment of Contingency Sum in Relation to the Total Cost of Renovation Work in Public Schools in Abuja,
Nigeria. International Journal of Managerial Studies and Research (IJMSR), 2(10), 55-63.

José, Ignacio., Ortiz-González., and Eugenio, Pellicer., and Gregory, Howell. (2014). Contingency Management in Construction Projects: A Survey of Spanish Contractors. International Group for Lean Construction, 195-206.

Joseph, Ignatius., Teye. Buertey., and Emmanuel, Abeere-Inga. Theophilus. Adjei. Kumi. (2012). Project Cost Contingency Estimation in Ghana: An Integrated Approach. Science Journal of Civil Engineering and Architecture, https:// DOI: 10.7237/sjcea/214

Khalafallah, Ahmed., and Moheeb, El-Said. (2005). Estimating residential Projects Cost Contingencies Using a Belief Network.

Kim, D. Y., and Han, S. H., and Kim, H. (2008). Discriminant analysis for predicting ranges of cost variance in international construction projects. Construction Engineering Management, 134(6), 398-410.

Lorance, R. B., and Wendling, R. V. (2001). Basic techniques for analysing and presenting cost risk analysis. Cost Engineering, 43(6), 25-31.

Mohamed, Ali. Yusuf. Alsendi. (2015). Studying the effect of decision making on delayed construction projects. Research Report, The George Washington University

Moselhi, O. (1997). Risk Assessment and Contingency Estimating. AACE Transactions, Dallas, DandRM/A 06

Musa, M. M., Zubairu, I. K. and Bala, K. (2011). Appraisal of the Performance of Contingency Cost Provision for Building Projects in Nigeria. ATBU Journal of Environmental Technology, 4(1)

Nurudeen, J. B. (2002). Statistical Theory and Analysis. Lagos Planet Press Publishers Ltd.

Osipova, Ekaterina., and Eriksson, Per-Erik. (2013). Balancing control and flexibility in joint risk management: Lessons learned from two construction projects. International Journal of Project Management, ISSN 0263-7863, E-ISSN 1873-4634, 31(3), 391-399.

Piero, Anticona. (2019). Strategies to include Contingency in Public Project Estimates. PM World Journal, VIII(III)

Randolph, E. Ruff., and Jonathan. M. Mraunac. (2018). The use and misuse of allowances and contractor contingency. Ogletree, Deakins, Nash, Smoak and Stewart, P.C.

Razali, Abdul. Hamid., and Fabi, Jonathan. Kehinde. (2017). Choosing an appropriate contingency sum estimating Methods for highway construction projects in Nigeria: A literature review - Planning Malaysia. Journal of the Malaysian Institute of Planners, 15(1), $13-20$.

Salant, P. and Dillman, D. (1994). How to Conduct Your Own Survey. John Wiley, New York.

Takim, R. Akintoye., and Kelly, J. (2003). Performance measurement systems in construction. In: Greenwood, D J (Ed.). 19th Annual ARCOM Conference, University of Brighton. Association of Researchers in Construction Management, 1, 423-32.

Touran, A. (2003). Probabilistic Model for Contingency. Journal of Construction Engineering and Management, 280-284. 


\section{Appendix: Questionnaire Sample}

(Please tick mark selected option)

\section{Demographic Details}

1. Name:

2. Type of Project Company:
a. Contractor
b. Vendor/Supplier
c. Customer
d. Consultant

3. Academic qualification
a. Diploma
b. B.E/B.Tech
c. Other Graduates
d. $\mathrm{PG} / \mathrm{PhD}$

4. Project Experience
a. 0 - 9
b. $10-15$
c. $15-20$
d. 21 and Above

\section{Questions}

1. Construction cost in $\%$ of project budget for Indian construction projects
a. $85 \%$ to $90 \%$
b. $80 \%$ to $85 \%$
c. $75 \%$ to $80 \%$
d. less than $75 \%$

2. \% of contingency reserve with respect to estimated cost considered in Indian construction projects
a. 0 to $5 \%$
b. 6 to $10 \%$
c. 11 to $15 \%$
d. More than $15 \%$

(Please tick mark option on scale of $1-5$, where $5=$ Strongly Agree, 4 = Agree, 3= Neither Agree or Disagree, $2=$ Disagree and $1=$ Strongly Disagree)

3. Objective of contingency management for Indian construction projects

a. Safeguarding optimum project cost as per project bidding price - $(1,2,3,4,5)$

b. Keeping project cost within PMB (Performance Measurement Baseline) throughout project tenure $(1,2,3,4,5)$

c. Contributing to the overall project firms objective of managing and mitigating unforeseen risk exposure $-(1,2,3,4,5)$

d. Ensuring meeting project cost and profit target $(1,2,3,4,5)$

4. Involvement of key stakeholders of Indian construction projects in contingency management

a. Project Proposal Cell - $(1,2,3,4,5)$

b. Project Planning Cell - $(1,2,3,4,5)$

c. Project Execution Cell - $(1,2,3,4,5)$

d. Project Finance and Accounts Cell - (1, 2, 3, 4, 5)

5. Selection criteria for contingency by Indian construction projects

a. Assumption based on addition of sum of considering formal risk analysis of project - $(1,2,3$, $4,5)$

b. Based on addition of sum reflecting in-built observation of risk - $(1,2,3,4,5)$ c. As per standard \% laid down under S.O.Ps - $(1,2$, $3,4,5)$

d. Suitable advice from project proposal or estimation cell - $(1,2,3,4,5)$

6. Which are the factors that determine the percentage addition of contingency to the project estimated cost?

a. Project Location and Geographical Conditions $(1,2,3,4,5)$

b. Amount and Volume of Project Work - (1, 2, 3, $4,5)$

c. Level of Project Rework - $(1,2,3,4,5)$

d. Project specific factors like type of client, duration etc. $-(1,2,3,4,5)$

7. Utilisation of contingency in Indian construction projects

a. To accommodate errors/omissions took-place in the estimation stage - $(1,2,3,4,5)$

b. To mitigate Project Risk and Uncertainties - (1, $2,3,4,5)$

c. To accommodate higher project spending due to cost overruns - $(1,2,3,4,5)$

d. To fulfil Project commitments in terms of schedule, quality and performance - $(1,2,3,4,5)$

8. Exclusion of contingency in Indian construction projects

a. Project Scope Change - $(1,2,3,4,5)$

b. Project unexpected work stoppage due to a strike, lockout etc. - $(1,2,3,4,5)$

c. Project Cost Variations due to Inflation and Currency fluctuations - $(1,2,3,4,5)$

d. Project Transferred Risk or Risk being taken care of by Project Insurance - $(1,2,3,4,5)$

9. Techniques of determining contingency in Indian construction projects

a. Traditional Percentage rate based on the historical project performance - $(1,2,3,4,5)$

b. Statistical Methods like Regression Analysis, Monte Carlo Simulation etc. - $(1,2,3,4,5)$

c. Project Risk Analysis and suggested outcome $(1,2,3,4,5)$

d. Project Scheduling Techniques like PERT and $\mathrm{CPM}-(1,2,3,4,5)$

10. Bottlenecks in contingency management in Indian construction projects

a. Lack of clarity about the construction project's objective on contingency management - $(1,2,3,4$, 5)

b. Ignorance about S.O.Ps/Process of contingency management - $(1,2,3,4,5)$

c. Lack of coordination between proposal and planning cell (in terms of proper estimation) and execution cell (in terms of effective utilisation) - (1, $2,3,4,5)$

d. Non-availability of proper data and poor understanding of project contingency reserve mechanism and instruments - $(1,2,3,4,5)$

11. Strategies for forecasting contingency in Indian construction projects

a. At the time of submitting a bid - $(1,2,3,4,5)$

b. At the time of receiving an order from the customer - $(1,2,3,4,5)$

c. At the time of project execution and cost overruns occasions - $(1,2,3,4,5)$ 
d. No fixed timeline and forecasting strategy - $(1,2$, $3,4,5)$

12. Areas of improvement for efficient contingency management for Indian construction projects

a. Identification of project contingency and execution strategy during project bid stage - $(1,2,3$, $4,5)$ b. Project contingency management awareness in terms of S.O.Ps, process and role clarity among project professionals - $(1,2,3,4,5)$

c. Aligning of proposal and planning cell (in terms of proper estimation) and execution cell (in terms of effective utilisation) activities - $(1,2,3,4,5)$

d. Availability and access to project contingency management database $-(1,2,3,4,5)$ 